\title{
A Strategic Approach to Crisis Management 2019 Golestan Province Floods by Using SWOT Method
}

\author{
Mohammad Hossein Yeylaghi Ashrafi $^{1} \mathbb{D}$, Elham Akhtari ${ }^{1} \mathbb{D}$, Naser Bay $^{2} \mathbb{D}$, Nader Oveisi $^{3} \mathbb{D}$
}

Date of submission: 25 Dec. 2020 Date of acceptance: 17 Mar. 2021

\section{Original Article}

\begin{abstract}
INTRODUCTION: At the time of natural disasters, various organizations are responsible for crisis management. Each organization holds responsibilities corresponding to its mission statement. The absence of coordination is one of the primary obstacles regarding crisis management at the time of the disaster, caused by inconsistent decisions and a lack of mutual perception of the crisis. The more compatible the strategy selection process of organizations is, the fewer natural disaster casualties will be.
\end{abstract}

METHODS: This study aims to strategically analyze the crisis management of April 2019 Golestan floods through the Strengths, Weaknesses, Opportunities, and Threats (SWOT) method, highlighting the role and performance of the Red Crescent Society. The selected tool was a descriptive-analytic field-based documentation survey questionnaire providing the chance to investigate the strengths, weaknesses, opportunities, and threats. Finally, we determined the optimal strategy.

FINDINGS: The results revealed that the average values of internal and external factors for all units were above 2.5. Therefore, SO is the optimal strategy whose emphasis is on using the strengths and opportunities faced by the Red Crescent Society to the fullest and other flood management bodies.

CONCLUSION: Considering that the crisis-management-related agencies ought to operate as a unified system to decrease casualties, the need to adopt proper strategies to enhance coordination in associated organizations is one of the leading priorities of Golestan Province.

Keywords: Crisis Management; Floods; Golestan Province; Strategy; SWOT.

How to cite this article: Yeylaghi Ashrafi MH, Akhtari E, Bay N, Oveisi N. A Strategic Approach to

Crisis Management 2019 Golestan Province Floods: by Using SWOT Method. Sci J Rescue Relief 2021; 13(2): 129-40.

\section{Introduction}

$\mathrm{N}$ atural disasters have always existed as recurring and adverse phenomena posing an immense threat to humans. Hence, no society is entirely immune from their consequences. Since the beginning of time, individuals and communities have taken various approaches to respond to disasters and catastrophes to lessen their impact, improve performance, and promote pre-and-post-crisis responses.

Man's attempts to deal with natural disasters in the modern era have three phases or approaches. The first phase/approach was developed based on emergency relief and rescue. Simultaneously, the International Federation of Red Cross and Red
Crescent (IFRC) Societies was established in the early twentieth century. This phase extended until the Second World War, through which emergency relief and humanitarian aid were provided to the victims. The second phase/approach took place following WWII. Back then, scientific and technical discourses, schools of thought concerned with growth and development, and post-war behaviorism dominated the United States, Europe, and later the rest of the globe. Based on this approach, measures were taken to avoid the adverse consequences of catastrophes and disasters. The approach prioritized preventing such calamities by applying scientific and engineering accomplishments in constructing and

1- Master of Management, Golestan Province Red Crescent Society, Golestan, Iran

2- PhD in Climatology, Golestan Province Red Crescent Society, Golestan, Iran

3- PhD in Air Pollution Environmental Engineering, Islamic Azad University, Science and Research Branch, Tehran, Iran Correspondence to: Naser Bay, Email: Naserbay1@gmail.com 
advancing artificial environments such as buildings, roads, and urban planning. The scientific and engineering approach to crisis management was the dominant approach until the 1980 s, and responsible international organizations such as the United Nations incorporated it as a principle in their programs. The disasters of the 1980s revealed that the scientific and engineering approach to tackling emergencies was not adequate since human factors and variables in preventing and dealing with catastrophes were left out. Consequently, the third phase/approach, called the social approach to crisis management, was gradually formed globally from the late 1980s and early 1990s. This approach, which emphasizes diminishing the risks in the individual and social environment of human beings against natural disasters, is now the dominant and comprehensive approach at the international level and in many countries (1).

Natural disasters have been among the most crucial issues in human societies since forever, and planning to overcome their harmful impacts is one objective of governments. Between 2000 and 2019, 7,348 disasters killed 1.23 million people, affected 4.2 billion people, and caused US\$2.97 trillion worth of damage to the world economy. However, these figures display a significant rise over the past 20 years. Between 1980 and 1999, 4,212 natural disasters occurred universally, killing 1.19 million people, injuring 3.25 billion people, and causing US\$1.63 trillion worth of economic damage. The foremost reason behind this upsurge is associated with weather-related disasters. Thus, these catastrophes grew from 3656 between 1980 and 1999 to 6681 between 2000 and 2019. Moreover, major floods occurred twice as many during this period reaching 3254 cases since 2010 (2).

A number of the most devastating recordbreaking precipitation episodes have occurred in the past two decades. Consequently, it is essential that flood control systems be able to defeat the challenges ahead. This resolution is of critical importance in flood risk management (3).

Investigating natural disasters and climaterelated risks is the prime element of crisis management strategies. Many researchers have been exploring this issue since the 1930s (4). Many studies reviewed the relationship between natural disasters and crisis management from different angles in Iran and other countries:
Afrakhteh and Yousefi (2004), Ildermi and Mirsanjari (2010), Mahdavi Najafabadi et al. (2010), Badri et al. (2013), Heidari et al. (2015), Kashkoli and Seidbeigi (2016), Hunkezehi and Fanni (2019), Dottori et al. (2016), Win et al. (2018), Horita et al. (2018), Entorf and Jensen (2020), and Saraswati et al. (2020).

Furthermore, regarding using the SWOT method in flood studies, we can refer to the investigations of Sadeghloo and Sajasi (2014) in Qarachai Ramian, Amini, and Banihabib (2015) in the catchment area of Wardavard River, Khalili et al. (2015) in the urban watershed of Fasa, and Khaledi et al. (2009) on urban floods in Urmia. They aimed to accommodate an appropriate strategy to manage and overcome the negative impacts of floods.

Floods, ice storms, forest and pasture wildfires, landslides, and droughts are the most significant disasters that have affected Golestan Province for at least the past 30 years. According to the statistics registered in the Relief and Rescue Organization database, Golestan Province is among the top three provinces in natural and artificial disasters. These disasters damage immense capital annually. One of the deadliest and most prominent ones is floods and heavy rains. For instance, about 300 people lost their lives in the 2001 flood solely (21).

The occurrence and frequency of disasters in Golestan indicate that the likelihood of most natural crises is inevitable. However, it is possible to diminish or even eliminate some of the harms and adverse consequences by predicting, preventing, and organizing crisis management. To achieve this goal, creating a coordination mechanism (job description, strategic action plan, repetition, and practice) in crisis management is one of the most vital and fundamental strategies to reduce the impact of natural disasters.

However, "this issue has been neglected in recent years due to the high frequency of disasters in the province and the extensive human and economic losses".

Apparently, the officials of the province should acknowledge the following factors concerning emergency response management:

\section{Recurrence of natural disasters}

This factor has influenced Golestan Province as an independent variable over time. Therefore, the issue of maintaining enhancing preparation 
is highly critical in emergency response management. This issue grows even more significant when we face climate changes that have intensified the impacts of disasters.

\section{Location}

Since we cannot make fundamental adjustments to lessen the impact of disasters on the morphology, hydrology, geology, soil texture, and other environmental variables of the province, we must contemporize all our arrangements with the current natural conditions.

Therefore, how the natural environment functions and operates is independent of human will, which along with recurrence over time, results in the irregular appearance of the previous episodes. For instance, the floods of the preceding years had struck some regions of the province, e.g., Mīnū Dasht and Aliabad-e-Katoul (two counties) in a short period due to unusual precipitation and other contributing factors in the basin.

However, the recent floods hit vast regions of the province simultaneously, causing a set of crises. The catastrophes included landslides and rockfalls on steep slopes and cliffs along the roads, floods in the streambeds, and floodwater in the catchments of the northern drainage basins.

Heavy precipitation began on 03/17/2019 and lasted till 04/01/2019 throughout the southern and southeastern regions of the Caspian Sea, causing the recent flash flood, unparalleled in $21^{\text {st }}$-century Iran. The rainfall and water accumulation area were approximately $8500 \mathrm{~km}^{2}$, comprising nearly $40 \%$ of the province. In the area in which floodwater accumulated, the mean precipitation was $178 \mathrm{~mm}$ from March 18 to March 22 for the whole area. This number is approximately $67 \%$ of the total annual long-term mean compared to the 50-year average. Gonbad-e Kavus, Anbār Olūm, Āq Qalā, Bandar Torkaman, and Gumshān were within the direct impact of the floods with a population of 211,000. Eighty-two villages with a population of nearly 103,500 people were located in the flood diffusion zone. This precipitation, prompting $308,000,000 \mathrm{~m}^{3}$ of flooding in the Gorganrood water catchment (Figure 1) and leaving destructive impacts on over $400 \mathrm{~km}^{2}$ of urban and rural areas, caused over 4800 billion tomans worth of economic damage (22).

The following points help you comprehend this flood's characteristics properly:
- The occurrence of unexpected and simultaneous precipitation in terms of intensity and duration throughout the southeastern regions of the Caspian Sea induced the production of an ample amount of runoff moving in the direction of topographic slope from south to north and east to west, starting from North Khorasan Province and finally discharging into the Caspian Sea, affecting towns and villages along the route (Figure 1)

- The presence of impermeable geological formations in the north of the province intensifying flooding (23)

- Constructing structures perpendicular to the water flow direction, namely roads and railways, not dredging the rivers, failure to acknowledge the geometric shapes and strength of hydraulic structures, and encroaching rivers in some areas (authors' observations)

- People's misjudgment regarding the intensity and extent of the flood and inadequate awareness-spreading from the officials led the residents not to have enough time to evacuate the target areas. On the other hand, some villagers resisted evacuating to protect livestock, property, and agricultural products disrupting the relief process (authors' observations)

- Assuming that the extent of floods was unforeseen and unparalleled, the desirable coordination was not carried out in the earlier days of the emergency. The personnel were not familiar with their organizational duties and job description at the time of the disaster. An example is forecasting flood risk by Golestan Meteorological Organization several days before the accident and announcing this issue as a formal statement to all people and departments, especially crisis-related organizations (authors' observations).

\section{Study Area}

Golestan Province covers 20,437.7 square kilometers $(1.3 \%$ of Iran's total area) and $1,868,819$ residents, located in the northeast of Iran. Roughly $51 \%$ of the population lives in urban areas and $49 \%$ in villages, most of whom make a living from agriculture, animal husbandry, and related industries (24). Topographically, the rugged regions in Golestan Province are part of the Alborz mountain range with an almost east-west direction. It has formed a mountainous area with a maximum height of 3821 meters in the southern part of the province. 


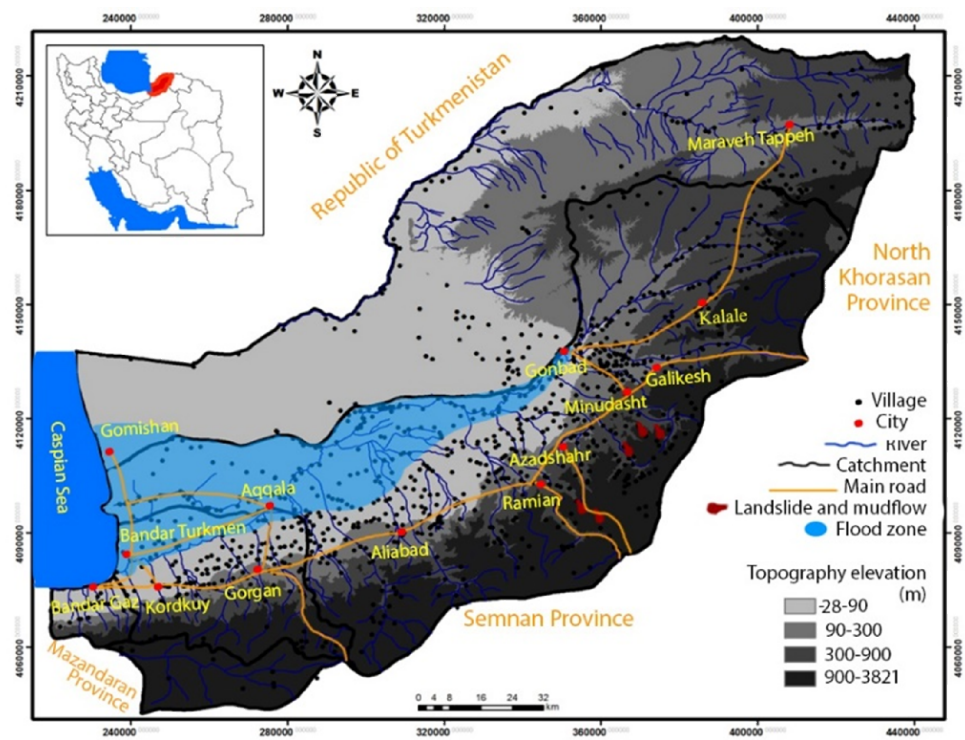

Figure 1. Direction of Flood Movements (22)

The slopes are steep, and the elevation varies abruptly from the plain to the mountain. The north of this area contains the lands of Mahur Hill, A.K.A, a thousand valleys hill. In the northernmost of the province, there are plain regions with gentle-slope surfaces gradually reaching lower areas with a minimum elevation of 28 meters (Figure 1). Vegetation in the Golestan Province is Caspian forests, of which 452,185 hectares cover hills and pastures, and 1,126,000 hectares cover the northern areas of the province.

The river network of the province includes the Gorganrood water catchment with an area of $10,120 \mathrm{~km} 2$, Atrak with $8600 \mathrm{~km} 2$, Karasu with $1610 \mathrm{~km} 2$, Gulf of Gorgan with $340 \mathrm{~km} 2$, and Nekarood with $330 \mathrm{~km} 2$ (Figure 1). The amount of surface water in different basins varies according to the shape, size, climatic conditions, vegetation, and other cases (25). The annual volume of these rivers is around 1235 million $\mathrm{m} 3$, $45-50 \%$ of which flows from February to April as floods caused by precipitation and snowmelt. Meanwhile, some of it flows in the form of seasonal flooding in summer and autumn. In general, $65 \%$ of the rivers in the province undergo flooding, which sometimes has destructive consequences considering the extent and intensity of the floods. In terms of seasonal distribution, summer and winter are the rainiest and driest seasons in the province, respectively (21).

Golestan Province has a remarkably diverse climate. The northern areas are cold with little rainfall, the west is moderately humid, the center is semi-humid and temperate, and the south is semi-cold with little precipitation (26). The average annual rainfall of the province in the past 50 years is $471 \mathrm{~mm}$. According to meteorological data, the rains leading to the flood had a significant numerical difference in various stations of the counties. The highest precipitation amount before the flood and the day it started was $354 \mathrm{~mm}$ throughout four days in Tuska Chal station in Minudasht. On the fourth day, the precipitation in most stations was little and close to zero. The lowest amount was $94 \mathrm{~mm}$ in Nodehe Malek and Khānbebin stations (22).

\section{Methods}

We employed a descriptive-analytic method in this field-documentary study. The technique was utilizing the open questionnaire of the SWOT model. It enabled us to investigate and compare strengths and weaknesses as well as opportunities and threats. The rationale behind the approach is that an effective strategy should maximize the strengths and opportunities of the system while minimizing weaknesses and threats (27). This method is an efficient tool for identifying environmental conditions and the internal capabilities of the organization. The foundation of this tool in strategic planning is to perceive the environment around the organization.

SWOT stands for Strengths, Weaknesses, Opportunities, and Threats. Strengths and weaknesses are internal factors, while threats and opportunities are external factors. 
To perceive the current crisis management in the March 2019 Golestan floods and formulate strategies, the research team conducted field observations, and crisis management experts completed the questionnaire. We collected the data from four perspectives, i.e., identifying strengths, weaknesses, opportunities, and threats through the following steps (Figure 1).

\section{Step 1: Identifying internal and external factors}

In the SWOT analysis, we firstly identified the internal and external factors. We selected CEOs, vice presidents, chiefs of staff, experts, relief employees, and rescue workers as the study population to complete the questionnaire. The inclusion criteria were sufficient information about crisis management, rescue operations, housing concerns, and active presence in the recent flood. The questionnaire was delivered either in person or via office automation. Out of 62 questionnaires, 50 were completed and delivered.

\section{Step 2: Weighted scoring and formulating IFE and EFE matrix}

After identifying the internal and external factors and classifying them, we had to determine the value of each. First, the factors were listed. Then, we assigned a number from 0 to 20 to each factor based on expert assessment. The weighted score given to each factor indicates its relative importance regardless of whether the factor in question is considered a strength, weakness, opportunity, or threat. We assigned the element with the most profound impact the highest score. Note that the sum of weighted scores should be equal to 1 . Hence we adjusted the range of values between 0 and 1 using the statistical method of normalization. Then, based on the prevailing condition of flood crisis management, we assigned each a mark between 1 and 4 to the factors, 1 indicating a poor situation and 4 registering an excellent one. Finally, we multiplied the normalized weighted scores by their mark, obtaining the final score.

\section{Step 3: Designing an analytical model and devising strategies}

IFE and EFE matrix is used to examine an organization's external environment. Therefore, to form it, we must place the scores obtained from the internal and external factor evaluation matrix in its vertical and horizontal dimensions to determine the positions and devise appropriate strategies.

\section{Findings}

Rescue and Relief Department (Emergency Operation Center (EOC), Rescue and Relief Support and Rescue and Relief Operation), Departments of Health, Volunteer Affairs, Youth Affairs, and Public Relations of the Red Crescent Society of Golestan Province were the active flood management units. The results showed 32 strengths, 53 weaknesses, 24 opportunities, and 28 threats, the most significant of which are listed in Table 1.

Table 1. The most significant internal and external elements influential in flood crisis management (obtained from the SWOT questionnaire)

\begin{tabular}{|c|c|c|c|c|c|c|}
\hline 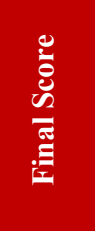 & 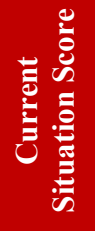 & 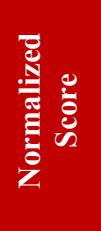 & 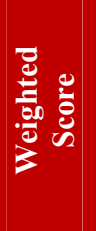 & Elements & Unit & Factor \\
\hline 0.229 & 2 & 0.114 & 12 & $\begin{array}{l}\text { Unavailability of the required information, e.g., } \\
\text { maps }\end{array}$ & $\mathrm{EOC}$ & Weakness \\
\hline 0.714 & 4 & 0.179 & 5 & $\begin{array}{l}\text { A quick assessment by teams at rescue and relief } \\
\text { stations }\end{array}$ & EOC & Strength \\
\hline 0.5 & 1 & 0.5 & 3 & $\begin{array}{c}\text { Deficiency of inter-organizational coordination and } \\
\text { operational planning }\end{array}$ & EOC & Threat \\
\hline 4 & 4 & 1 & 1 & $\begin{array}{l}\text { Familiarity with how the Health Information } \\
\text { Software (NAB) functions in emergencies }\end{array}$ & EOC & Opportunity \\
\hline 0.364 & 2 & 0.182 & 10 & $\begin{array}{c}\text { Ambiguousness of the commands by the executive } \\
\text { units in emergency accommodation }\end{array}$ & $\begin{array}{l}\text { Rescue and } \\
\text { Relief Support }\end{array}$ & Weakness \\
\hline 0.857 & 4 & 0.124 & 6 & $\begin{array}{l}\text { Maximum participation of rural aid workers and } \\
\text { teams regardless of the village dispersions }\end{array}$ & $\begin{array}{c}\text { Rescue and } \\
\text { Relief Support }\end{array}$ & Strength \\
\hline
\end{tabular}




\section{Table 1. Continued}

\begin{tabular}{|c|c|c|c|c|c|c|}
\hline 2 & 2 & 1 & 1 & $\begin{array}{l}\text { Failure to take in-time action by the responsible } \\
\text { institutions in identifying and evaluating houses in } \\
\text { flooded areas }\end{array}$ & $\begin{array}{l}\text { Rescue and } \\
\text { Relief Support }\end{array}$ & Threat \\
\hline 3 & 3 & 1 & 1 & $\begin{array}{c}\text { Proposing the support capacities of certain } \\
\text { provinces }\end{array}$ & $\begin{array}{l}\text { Rescue and } \\
\text { Relief Support }\end{array}$ & Opportunity \\
\hline 0.235 & 3 & 0.078 & 12 & $\begin{array}{l}\text { Flooding of relief depots and emergency } \\
\text { accommodation }\end{array}$ & $\begin{array}{c}\text { Rescue and } \\
\text { Relief Operation }\end{array}$ & Weakness \\
\hline 0.888 & 4 & 0.222 & 8 & $\begin{array}{c}\text { Decent air rescue performance at the time of the } \\
\text { disaster }\end{array}$ & $\begin{array}{c}\text { Rescue and } \\
\text { Relief Operation }\end{array}$ & Strength \\
\hline 0.545 & 3 & 0.182 & 10 & $\begin{array}{l}\text { Air relief services to challenging areas due to } \\
\text { severe weather phenomena }\end{array}$ & $\begin{array}{c}\text { Rescue and } \\
\text { Relief Operation }\end{array}$ & Threat \\
\hline 1 & 4 & 0.250 & 7 & Enhancing operational skills & $\begin{array}{c}\text { Rescue and } \\
\text { Relief Operation }\end{array}$ & Opportunity \\
\hline 1.333 & 2 & 0.667 & 2 & $\begin{array}{l}\text { Less scrutiny toward youth activities and facilitation } \\
\text { of various youth centers in helping the victims }\end{array}$ & Youth Affairs & Weakness \\
\hline 2.668 & 4 & 0.667 & 2 & $\begin{array}{c}\text { Voluntary participation of members to assist at } \\
\text { times of emergency }\end{array}$ & Youth Affairs & Strength \\
\hline 3 & 3 & 0.667 & 2 & $\begin{array}{l}\text { The unclarity of Mental Health Support } \\
\text { Ambassadors (SAHAR) for the people, } \\
\text { diminishing the efficacy of services }\end{array}$ & Youth Affairs & Threat \\
\hline 3 & 3 & 1 & 1 & $\begin{array}{l}\text { Identifying the potentials of departments affiliated } \\
\text { with mission areas and using their capacity }\end{array}$ & Youth Affairs & Opportunity \\
\hline 0.999 & 3 & 0.333 & 2 & $\begin{array}{l}\text { Submitting reports on the services of all sections of } \\
\text { the Red Crescent Society in the initial days }\end{array}$ & Public Relations & Weakness \\
\hline 3 & 3 & 1 & 1 & $\begin{array}{l}\text { Raising public awareness about the performance of } \\
\text { the Red Crescent Society }\end{array}$ & Public Relations & Strength \\
\hline 2 & 3 & 0.667 & 2 & $\begin{array}{l}\text { Misinterpretation of the Red Crescent activities by } \\
\text { the public and organizations }\end{array}$ & Public Relations & Threat \\
\hline 1.5 & 3 & 0.5 & 3 & $\begin{array}{l}\text { Demonstrating the focus of the services of the } \\
\text { organizations for the public highlighting the } \\
\text { activities of the Red Crescent Society }\end{array}$ & Public Relations & Opportunity \\
\hline
\end{tabular}

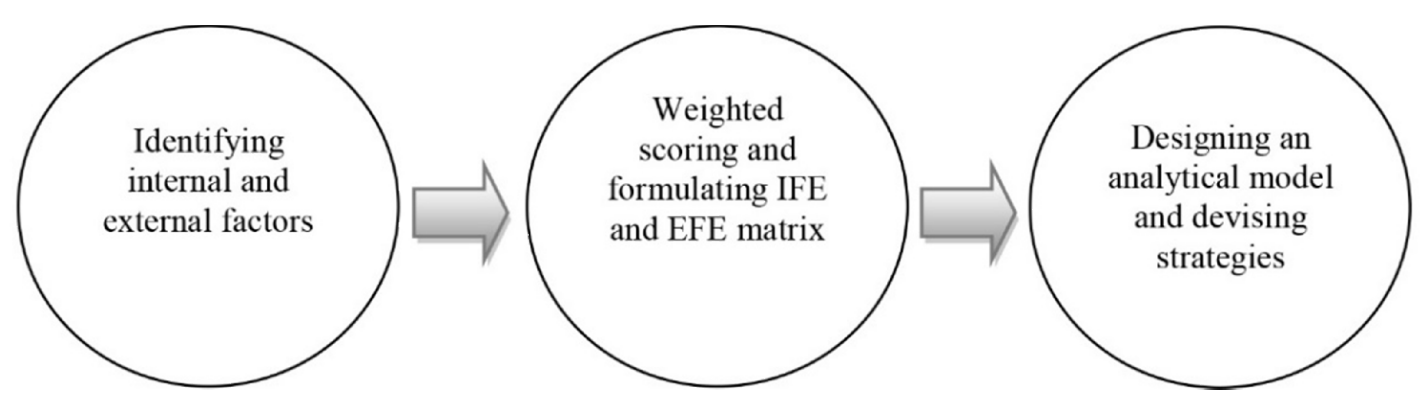

Figure 2. The research method

In terms of number, negative factors are dominant. However, the score obtained from the matrix of internal and external elements is above 2.5. Therefore, in the crisis management process, the strengths are more impactful than weaknesses, and opportunities are more significant than threats. The rescue and relief operation unit had a more successful performance than other units, with a score of
3.11 in internal and 3.13 in external factors. Furthermore, by curve fitting the final scores of internal and external factors in relation to one another, the strategies of each unit were determined (Table 3).

We obtained the optimal strategy (SO) by plotting the mean values of the internal (2.74) and external (2.91) factors on the coordinate axis, highlighting how to make the most of the 
opportunities by utilizing the strengths (Figure 3).

Table 2. Values of internal and external elements influential in flood crisis management (obtained from the SWOT questionnaire)

\begin{tabular}{|c|c|c|c|c|}
\hline Mean value of scores & Sum of final scores & Number & Factor & Unit \\
\hline \multirow{2}{*}{2.6} & 1.6 & 14 & Weaknesses & \multirow{4}{*}{ Emergency Operation Center } \\
\hline & 3.6 & 7 & Strengths & \\
\hline \multirow{2}{*}{2.5} & 1 & 3 & Threats & \\
\hline & 4 & 1 & Opportunities & \\
\hline 2.78 & 1.96 & 10 & Weaknesses & \multirow{4}{*}{ Rescue and Relief Support } \\
\hline 2.18 & 3.6 & 7 & Strengths & \\
\hline \multirow[t]{2}{*}{2.5} & 2 & 1 & Threats & \\
\hline & 3 & 1 & Opportunities & \\
\hline 311 & 1.87 & 17 & Weaknesses & \multirow{4}{*}{ Rescue and Relief Operation } \\
\hline 3.11 & 4.36 & 8 & Strengths & \\
\hline \multirow{2}{*}{3.13} & 2.345 & 10 & Threats & \\
\hline & 3.92 & 7 & Opportunities & \\
\hline & 1.40 & 5 & Weaknesses & \multirow{4}{*}{ Volunteer Affairs } \\
\hline 2.5 & 3.6 & 4 & Strengths & \\
\hline \multirow{2}{*}{3.47} & 2.4 & 5 & Threats & \\
\hline & 4.55 & 8 & Opportunities & \\
\hline 2.5 & 2 & 2 & Weaknesses & \multirow{3}{*}{ Health and Treatment } \\
\hline \multirow{2}{*}{3.41} & 3 & $\begin{array}{l}3 \\
5\end{array}$ & Strengths & \\
\hline & $\begin{array}{c}3.33 \\
3.5\end{array}$ & $\begin{array}{l}5 \\
3\end{array}$ & $\begin{array}{l}\text { Threats } \\
\text { Opportunities }\end{array}$ & \\
\hline & 1.66 & 2 & Weaknesses & \multirow{4}{*}{ Youth Affairs } \\
\hline 3.33 & 5 & 2 & Strengths & \\
\hline 2.83 & 2.66 & 2 & $\begin{array}{c}\text { Threats } \\
\text { Opportunities }\end{array}$ & \\
\hline & 3 & 1 & epportumiles & \\
\hline \multirow{2}{*}{2.5} & 2 & 3 & Weaknesses & \multirow{4}{*}{ Public Relations } \\
\hline & 3 & 1 & Strengths & \\
\hline \multirow[t]{2}{*}{2.76} & 2.66 & 2 & Threats & \\
\hline & 3.33 & 3 & Opportunities & \\
\hline
\end{tabular}

Table 3. Strategies obtained from the SWOT analysis

Updating, equipping, and developing the Operation Control Center in terms of software information systems, maps, computers, and qualified staff

Utilizing helpful experiences of certain provinces in similar circumstances in the form of holding training workshops or sending reports to prevent self-endeavor
Using the results of field research studies in the country's research centers in coordination with the General Directorate of Crisis Management

- Holding regular meetings in the Rescue and Relief Administration focusing on establishing coordination and eliminating the current operational defects

- Defining Code Two for the employees and acknowledging the secondary duties of the employees at the time of crises to maintain the energy of the colleagues involved in disaster management

\section{- Developing operational} planning for interorganizational coordination by holding regular meetings of the committee members

- Holding roundtable and operational maneuvers throughout the year and developing various scenarios

- Educating rescue workers in the villages to identify aid, accommodation, and assessment in the early hours of the affected areas

- Identifying and organizing the logistic potential of volunteers for times of emergency
Cooperation with the province's university of medical sciences to use $\mathrm{NAB}$ for potential future crises

- Communication of Golestan Red Crescent Society with the center regarding equipping relief depots and delivery of new relief vehicles

- Repairing worn automobiles and equipment

- Communication of Golestan Red Crescent Society with the administrations concerning the introduction of indoor spaces for housing and Code Two training of non-relief colleagues
EOC

Rescue and

Relief Support 


\section{Table 3. Continued}

- Rendering Code

Two and educating personnel of other organizations

- Rereading, training, and implementing the emergency response program

- Using social media to identify active volunteers and instantly issue IDs for them

- Employing volunteers expert at system design for integrated management of relief depots in the affected areas

Explaining the duties of the Health and

Treatment and Youth Affairs Departments to prevent interference in the execution of duties

Avoiding naming projects with titles that do not reveal the essence of the project

(e.g., SAHAR)

Establishing a documentation unit in the Rescue and Relief Administration
Developing technical instructions for circumstances where there is a vacancy to prevent self-endeavor

- Holding elementary voluntary training courses for members to get acquainted with the principles of the Red Crescent Society

- Clarifying the status of the volunteers and the organizational identity (uniforms, covers, etc.) specific to the incident to reinforce the sense of belonging and identity for the volunteer and prevent possible misuse

Appointing the organizations responsible for providing health services for the potential future emergencies

Issuing IDs instantly for active members

Raising public awareness on the performance of the Red

Crescent Society, mainly via cyberspace and mass media
- Holding courses to

familiarize organizations with their duty descriptions and

those of other organizations and conducting joint maneuvers

- Communication of the society of Golestan with those of certain provinces concerning executing joint maneuvers

- Displaying commitment and assistance of volunteers in helping the victims to increase public trust placed in the Red Crescent Society - Spreading information decently about innovative fundraising methods, such as USSD codes

Collaborating in upgrading Health Information Software (NAB) of Golestan University of Medical Sciences based on the operational needs of the Red Crescent Society

Holding briefings for younger members to deliver the considerations of attending a disaster and relief area

Holding meetings with radio and television stations and news agencies to coordinate spreading information to individuals at times of crises
Repeating and practicing intraand-inter-organizational ISC in compliance with recurring crises as well as newfound ones

Rescue and Relief Operation
- Drawing new contributors by organizing active volunteers, especially by using the potential of cyberspace to coordinate donors

- Defining and explaining tasks and types of envisaged actions for emergencies (four main groups of volunteers)

Organizing volunteer physicians, paramedics, and health contributors in the form of health caravans by calling the

Basic Health Care Unit (BHCU)

\section{Developing programs for} recruiting and retaining members to assist the society during emergencies

- Holding public relations training courses for volunteers regarding experience sharing and its application in disasters - Forming volunteer broadcast teams for times of crisis
Health and

Treatment

Youth Affairs

Public

Relations

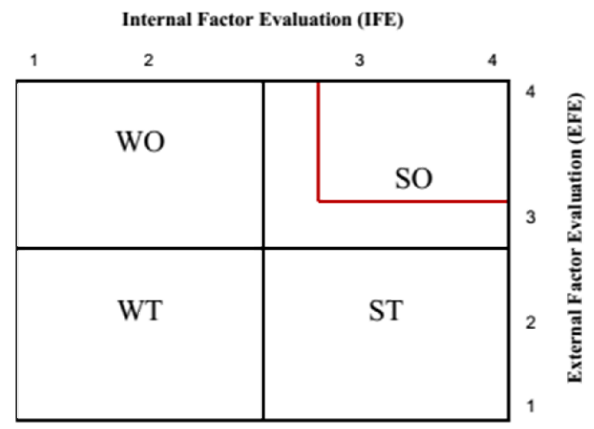

Figure 3. IFE, EFE matrix 


\section{Discussion and Conclusion}

In the face of a disaster, the government policies and strategies and non-governmental organizations, e.g., the Red Crescent Society, are the

most attention-grabbing items. The prevailing atmosphere in the previous critical circumstances shows that in the first moments or even the first days of the emergency, some individuals and organizations get bewildered and commit the simplest yet the hugest mistakes. Thus, crisis unavoidably impairs decision-making in three regards: it threatens the high-priority and vital goals of the decision-making unit, restricts the reaction time to make a decision, and overwhelms the decision-making units with its sudden emergence. Therefore, the decisions fluctuate according to the severity of the threat, the duration, and the awareness level. Although making critical and hasty calls are among the primary and fundamental operations of crisis management, the quality of the decision is momentous, which is a subordinate of the organization's strategies at the time of crisis. Strategic measures of Integrated Flood Management (IFM) a holistic approach, implying the close relationship between strategic planning and crisis management. The characteristics of the similarities and tendencies of the two help to describe the relationship between them. A crisis can likewise alter the current strategy and strategic efforts in a community or organization. Meanwhile, not taking strategic measures in crisis management increases the likelihood of emergencies; because in strategic planning, it is feasible to simultaneously pay attention to internal and external factors and forces influencing the crisis management process and facilitates integrated crisis management. This notion is particularly considerable for flood risk, which is the outcome of various internal and external factors. Conclusively, integrated flood risk management is a development process promoting an integrated approach to flood management rather than a fragmented one (17).

The Red Crescent Society of Golestan Province should use the SO strategy, an active solution, to obtain a situation where it can use its strengths to make the best use of opportunities in the external environment and expand its services. Therefore, it must maximize both its strengths and opportunities. Strengthening the vertical and horizontal intra-andinter-organization coordination will generate this outcome (Figures 4 and 5).

Coordination is the process where all the components in a system join to achieve a common goal. Therefore, coordination is achieved through a set of structural and behavioral mechanisms. It organizes the elements within an organization and also facilitates organizational goals. Prerequisites to achieve coordination include a stress on the social approach to crisis management, shared understanding of crisis management by people and the government, and selecting an adaptable and efficient organizational model for leading the forces and organizations affiliated with crisis management.

The models focus on promoting interorganizational and intraorganizational coordination and effective mutual communication in the Red

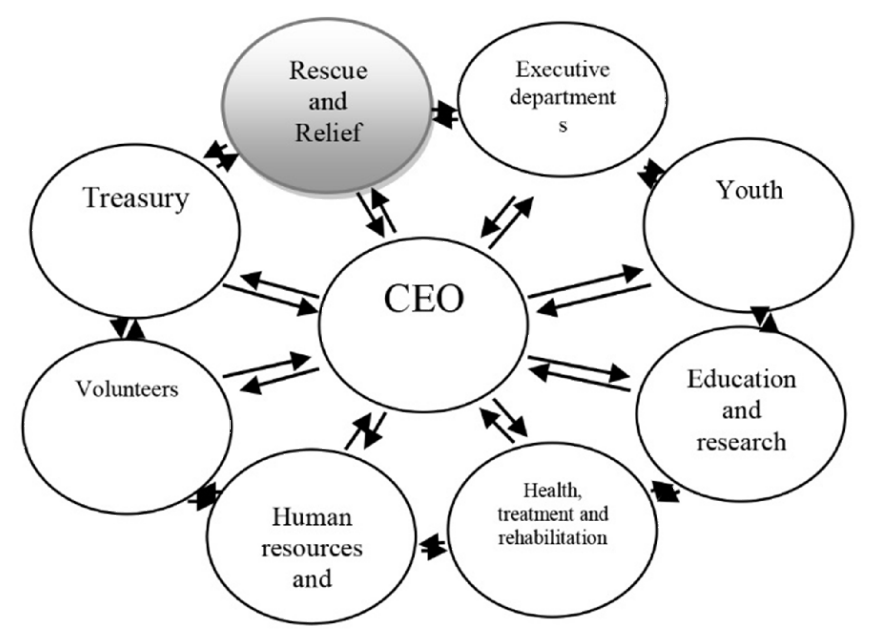

Figure 4. Proposed schematic diagram to increase intraorganizational coordination (authors) 


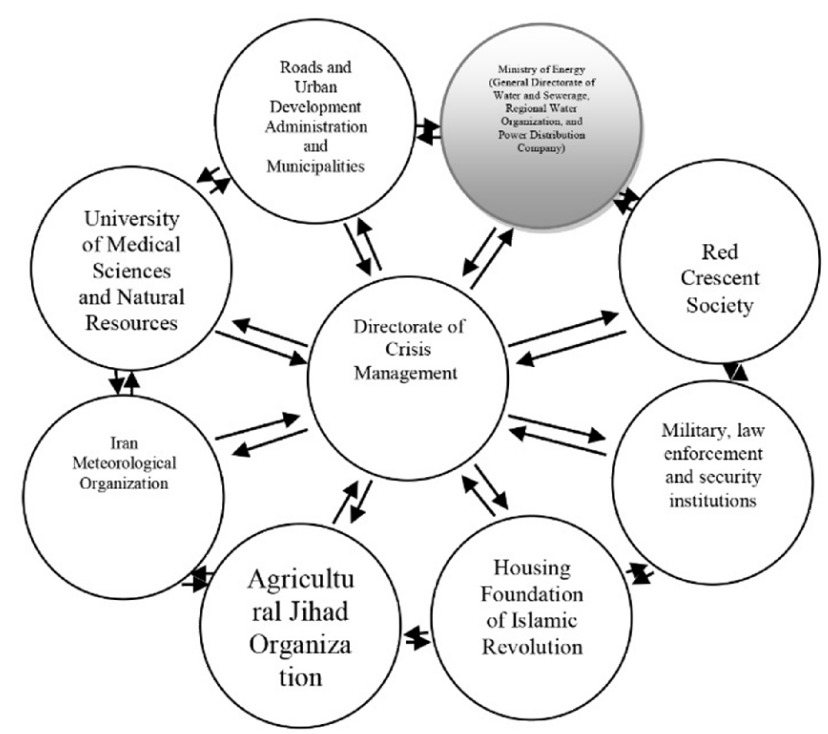

Figure 5. Proposed schematic diagram to increase interorganizational coordination (authors)

Crescent Society (Departments of Rescue and Relief) and Crisis Management and Planning Directorate (General Administrations under the Ministry of Energy), respectively. Thus, in the proposed system, each factor should affect the rest and be positively affected by them based on the following strategies, the feedback of which will strengthen the systematic relationship between the components, enhance task execution, and improve system performance.

\section{Strategies}

1. The top priorities of the Red Crescent Society as the housing custodian included identifying and meeting the daily needs of age and sex groups in every camp and recognizing the real flood victims, considering the flood extent and number of affected cities and villages. The affected areas were sometimes considerably far from each other. The organization achieved the goals using the Health Information Software (NAB) and cooperation with the province's university of medical sciences. Therefore, we suggest that the mentioned software platform be provided to the Red Crescent Society for potential future crises or be included in the crisis management program of the province so that other organizations get to be familiar with it in joint maneuvers.

2. The extent of the recent floods showed that the number of warehouses, ambulances, and similar equipment is not enough in the province in case of recurrence. Therefore, the Red Crescent
Society should be promoted from level 2 to level 1 to afford the workforce and other pieces of equipment by presenting the field research facts of the province to the society and expanding ties with it. In addition, to provide the required workforce in times of emergency, teaching Code Two to non-relief colleagues should be on the schedule.

3. All executive bodies of the province should provide their indoor information and latest IDs to the Red Crescent Society once every three months.

4. According to the definite plan and schedule of crisis management in Golestan Province, all the following systems of specialized working parties are required to implement ISC according to their job descriptions inside and outside the organization and submit reports.

5. The strong attendance of provincial and national philanthropists and people of different expertise and capabilities during the floods revealed talented volunteers whose potential has been neglected for whatever reason. Therefore, the Red Crescent must utilize people's capacities optimally and encourage them to join the society by reconsidering the employment of the volunteers.

6. Acknowledging the requirements of the injured for therapeutic services of physicians and paramedics, organizing health volunteers and philanthropists, and interacting with the University of Medical Sciences and Welfare Organization to set up health caravans are among 
the topmost priorities.

7. It is vital that we start programs to employ and retain new members since recruiting and retaining volunteer forces has been one of the major concerns of the Red Crescent Society in recent years. We have witnessed a decrease in rescue and relief workers.

8. Paying heed to the value of empiricism and the necessity to record events and present accurate and up-to-date news to the public, holding training courses for volunteer journalists, and forming news units are crucial strategies in the field of public relations.

9. Since crisis management is rooted in an inter-organization process, the demand for strategic planning in the province is noticeable more than ever. We review it at three levels. Firstly, strategies should be formulated according to field facts. Secondly, the resources of all organizations must be able to execute those strategies. Finally, there should be proper interorganizational coordination (IOC) before, during, and after the crisis. The last one seems to be the most influential element of strategic planning. Coordination is a process that prevents the waste of time, capital, and human services during a crisis and increases the efficiency and efficacy of crisis management elements and human resources in the pre-crisis period, during rescue operations, and even during temporary accommodation and reconstruction. Since the natural disasters in the province are recurring and diverse, crisis management requires an extensive and efficient coordination mechanism demanding appropriate strategies, continuing studies, and evaluating processes.

\section{Acknowledgments}

We sincerely thank all the staff and members of the Red Crescent Society who contributed to this study.

\section{Conflict of Interests}

Authors declared no conflict of interests regarding the publication of the present study.

\section{References}

1. Mohaghegh M. New approaches in crisis management and disaster risk reduction. Sci J Rescue Relief 2012; 4(3): 107-10. (In Persian)

2. United Nations Office for Disaster Risk Reduction. The UN office for disaster risk reduction, the human cost of disasters: an overview of the last 20 years (2000-2019). Geneva: United Nations Office for Disaster Risk Reduction; 2020.

3. Zhou Q, Mikkelsen PS, Halsnæs K, ArnbjergNielsen K. Framework for economic pluvial flood risk assessment considering climate change effects and adaptation benefits. J Hydrol 2012; 414: 53949.

4. Patrick L, Solecki W, Jacob KH, Kunreuther H, Nordenson G. New York City panel on climate change 2015 report chapter 3: static coastal flood mapping. Ann N Y Acad Sci 2015; 1336(1): 45-55.

5. Afrakhteh $H$. Rurbanism and environmental disaster case study: Robat-Karim. Urban Regional Stud Res 2004; 1(4): 37-58. (In Persian)

6. Eildermi A, Mirsanjari M. The analysis and zoning of environmental hazard in Slopes of Hamedan city. Environ Res 2011; 1(2): 67-77.

7. Najafabadi RM, Ramesht MH, Ghazi I, Khajedin SJ, Seif A, Nohegar A, et al. Identification of natural hazards and classification of urban areas by TOPSIS model (case study: Bandar Abbas city, Iran). Geom Natl Hazards Risk 2016; 7(1): 85-100. (In Persian)

8. Badri SA, Ramezanzadeh LM, Asgari A, Ghadiri MM, Salmani M. The role of local management in improving resilience to natural disasters with emphasis on floods case study: Cheshmeh Kileh basin in Tonekabon County and Sardabrood basin in Kelardasht County. Emerg Manag 2013; 2(3): 37-48. (In Persian)

9. Heidari R, Hosseini SA, Mousavi GH, Safari N. The analysis of preparedness for governmental organizations dealing with natural disasters in Rasht city. Sci J Rescue Relief 2014; 7(3): 27-43. (In Persian)

10. Kashkoli MR, Seedbeigi P. The role and position of urban planning in reducing the effects of natural disasters, floods and earthquakes in Asad Abad city by using SWOT analysis. Shebak 2016; 2(9-8): 2945. (In Persian)

11. Honkezehi MA, Fani Z. Reduce the effects of natural hazards (earthquakes) on urban environments with an emphasis on capacity building (case study: Zahedan city). Res Earth Sci 2019; 10(39): 191-213. (In Persian)

12. Dottori F, Salamon P, Bianchi A, Alfieri L, Hirpa FA, Feyen L. Development and evaluation of a framework for global flood hazard mapping. Adv Water Resour 2016; 94: 87-102.

13. Win S, Zin WW, Kawasaki A, San ZM. Establishment of flood damage function models: a case study in the Bago River Basin, Myanmar. Int $\mathbf{J}$ Disaster Risk Red 2018; 28: 688-700.

14. Horita FE, de Albuquerque JP, Marchezini V. Understanding the decision-making process in disaster risk monitoring and early-warning: a case 
study within a control room in Brazil. Int J Disaster Risk Red 2018; 28: 22-31.

15. Entorf H, Jensen A. Willingness-to-pay for hazard safety-a case study on the valuation of flood risk reduction in Germany. Saf Sci 2020; 128: 104657.

16. Thapa S, Shrestha A, Lamichhane S, Adhikari R, Gautam D. Catchment-scale flood hazard mapping and flood vulnerability analysis of residential buildings: the case of Khando River in eastern Nepal. J Hydrol Regional Stud 2020; 30: 100704.

17. Sadeghloo T, Sajasi Gidari H. Flood risk management strategies in rural areas with SWOCTOPSIS model (case study of Ghareh Chay river basin of Ramayan). Geography Environ Hazards 2014; 3(12):105-28. (In Persian)

18. Amini M, Bani Habib MA. Algorithm for determining the best strategy in flood management. Third National Conference on Flood Management and Engineering with Urban Flood Approach, Tehran, Iran; 2016. (In Persian)

19. Khalili A, Saeedeh Khalavii S, Malekian A. Investigation of urban flood risks by using SWOT approach. International Conference on Society and Environment, Tehran, Iran; 2018. (In Persian)

20. Khaledi S, Ghahroudi Tali M, Farahmand G. Measuring and evaluating the resilience of urban areas against urban flooding (Case study: Urmia City). Sustainable Dev Geographic Environ 2018;
1(2): 1-5. (In Persian)

21. Bay N, Montazeri M, Gandomkar A. The study of the effect of Hydro-Climate factors on natural hazards in Golestan province with emphasis on flood. Quart Sci J Rescue Relief 2013; 5(2): 1-13. (In Persian)

22. Baitullahi A. Report of Golestan flood risk working group. Tehran: Ministry of Road \& and Urban Development Islamic Republic of Iran; 2019. P. 142. (In Persian)

23. Geological map of Golestan province with a scale of 1:100000. Tehran: Geological Organization \& Mineral Exploration of Iran; 2009. (In Persian)

24. Statistical Yearbook of Golestan Province. Deputy of statistics and information of Golestan province program and budget organization. Gorgan: Statistical Yearbook of Golestan Province; 2016. P. 1-747. (In Persian)

25. Regional Water Company of Golestan. Available at: URL: www.gsrw.ir; 2020. (In Persian)

26. Montazeri M, Bay N. Climatic regionalization of Caspian region using multivariate statistical methods. Geographical Res Quart J 2012; 27(2): 77-90. (In Persian)

27. Hekmatnia H, Mousavi MN. Application of model in geography with emphasis on urban and regional planning. Yazd, Iran: Elm-e-Novin Publication; 2006. P. 129. (In Persian) 